\section{Study of hypothalamic metabolism in cluster headache by proton MR spectroscopy}

Abstract-The authors used ${ }^{1} \mathrm{H}-\mathrm{MRS}$ to investigate hypothalamic metabolism in 26 patients with cluster headache $(\mathrm{CH})$ and 12 healthy subjects. Hypothalamic $N$-acetylaspartate/creatine was reduced in patients with $\mathrm{CH}$ vs controls $(p<0.01)$. Dividing the patients into episodic $\mathrm{CH}$ outside- and in-cluster periods and chronic $\mathrm{CH}$, the hypothalamic $N$-acetylaspartate/creatine in all three subgroups of patients was reduced. The reduction of the neuronal marker $\mathrm{N}$-acetylaspartate is consistent with hypothalamic neuronal dysfunction in patients with $\mathrm{CH}$.

NEUROLOGY 2006;66:1264-1266

\author{
R. Lodi, MD; G. Pierangeli, MD; C. Tonon, MD; S. Cevoli, MD; C. Testa, PhD; G. Bivona, MD; \\ F. Magnifico, MD; P. Cortelli, MD; P. Montagna, MD; and B. Barbiroli, MD
}

Cluster headache $(\mathrm{CH})$ is characterized by severe unilateral orbital, supraorbital, and/or temporal pain associated with cranial ipsilateral parasympathetic activation and sympathetic deficit. Attacks last from 15 to 180 minutes, and there can be as many as eight per day. In episodic $\mathrm{CH}$, attacks occur in clusters lasting 7 to 365 days separated by pain-free periods of $\geq 1$ month. In chronic $\mathrm{CH}$, affecting one-fifth of patients, attacks recur over $>1$ year without remission periods or with remission periods lasting $<1$ month. ${ }^{1}$

The striking circadian rhythmicity of $\mathrm{CH}$ attacks has pointed to the hypothalamus as a strong candidate site for triggering the attack. Functional neuroimaging studies performed using PET in patients with chronic $\mathrm{CH}$ during nitroglycerin-induced attacks showed increased blood flow in the ipsilateral hypothalamic gray matter. ${ }^{2}$ Using a voxel-based morphometric (VBM) analysis of MRI, structural differences in gray matter density consistent with an increased volume have been detected bilaterally in the hypothalamus of patients with $\mathrm{CH}$ either in or outside a cluster. ${ }^{3}$

Proton MR spectroscopy $\left({ }^{1} \mathrm{H}-\mathrm{MRS}\right)$ allows the noninvasive and spatially resolved measurement of several brain compounds including $N$-acetylaspartate (NAA), a neuronal marker that is reduced when neuronal dysfunction or loss occurs. In this study, we used ${ }^{1} \mathrm{H}$-MRS to investigate whether biochemical abnormalities consistent with functional or structural changes are present in the hypothalamus of patients with $\mathrm{CH}$.

From the Dipartimento di Medicina Clinica e Biotecnologia Applicata (R.L., C. Tonon., C. Testa, G.B., B.B.), Policlinico S. Orsola-Malpighi, Università di Bologna, Italy; and Dipartimento di Scienze Neurologiche (G.P., S.C., F.M., P.M.), Università di Bologna, Italy.

Disclosure: The authors report no conflicts of interest.

Received July 26, 2005. Accepted in final form January 16, 2006.

Address correspondence and reprint requests to Dr. Raffaele Lodi, Dipartimento di Medicina Clinica e Biotecnologia Applicata "D. Campanacci," Università di Bologna, Policlinico S. Orsola, Via Massarenti 9, 40138 Bologna, Italy; e-mail: raffaele.lodi@unibo.it
Methods. Twenty-six patients with $\mathrm{CH}$ (aged 26 to 67 years; 24 men and two women) (table) and 12 healthy controls (26 to 65 years; 11 men and one woman) were recruited. According to the International Classification of Headache Disorders II criteria ${ }^{1} 18$ patients had episodic $\mathrm{CH}$ and eight had the chronic form. Among the patients with episodic $\mathrm{CH}$, eight were scanned outside and ten, all pain-free, within the cluster.

${ }^{1} \mathrm{H}-\mathrm{MRS}$ studies were performed in a 1.5-T GE scanner as previously described. ${ }^{4} \mathrm{~A}$ volume of interest (VOI) ranging from 1 to $1.2 \mathrm{~cm}^{3}$ was selected to include bilateral hypothalamic gray matter (figure 1). Spectra were acquired using the PRESS single voxel sequence $(\mathrm{TR}=1500 \mathrm{msec} ; \mathrm{TE}=144 \mathrm{msec}$; number of acquisitions $=1536$ ). In 23 patients with $\mathrm{CH}$ and 11 healthy controls, two additional spectra were acquired from the mid-line parietal-occipital cortex and left parietal white matter (VOI $=8$ $\left.\mathrm{cm}^{3}\right)(\mathrm{TR}=1500 \mathrm{msec} ; \mathrm{TE}=40 \mathrm{msec} ;$ number of acquisitions $=$ 128). Automatic shimming was used. Typically, the water line width was around 5 to $7 \mathrm{~Hz}$ for hypothalamic VOIs, whereas a line width of 3 to $4 \mathrm{~Hz}$ could be achieved in white matter and cortical VOIs. The greater spectral resolution permitted the use of a short echo time, giving a substantially increased signal-to-noise ratio for a given scan duration, at the expense of more complex peak quantitation.

Peak areas for NAA, creatine-phosphocreatine (Cr), and choline (Cho) were calculated using the time domain fitting program AMARES/MRUI. Peak integral values were expressed relative to the $\mathrm{Cr}$ peak.

Significance, taken as $p<0.05$, was determined by the Student $t$ test for unpaired data when all patients with $\mathrm{CH}$ were compared to controls, and Fisher's protected least significant difference test (post hoc analysis of variance) when the three subgroups of patients with $\mathrm{CH}$ and controls were compared. Linear regression analysis was used to calculate correlation coefficients.

Results. In patients with $\mathrm{CH}$, hypothalamic NAA/Cr $(1.63 \pm 0.21)$ was reduced compared to controls (1.94 \pm $0.27 ; p=0.0004$ ) (figure 1 ), whereas $\mathrm{Cho} / \mathrm{Cr}$ was similar in patients with $\mathrm{CH}(1.85 \pm 0.33)$ and healthy controls $(1.96$ $\pm 0.26 ; p=0.3)$. In patients with $\mathrm{CH}$, hypothalamic NAA/ Cho was also reduced $(0.88 \pm 0.09$ vs $0.99 \pm 0.12$ in controls; $p=0.002)$. Dividing our patients into episodic $\mathrm{CH}$ outside- $(\mathrm{n}=8)$ and in-cluster periods $(\mathrm{n}=10)$ and chronic $\mathrm{CH}(\mathrm{n}=8)$, the hypothalamic $\mathrm{NAA} / \mathrm{Cr}$ in all three subgroups of patients was lower than in healthy controls: $1.65 \pm 0.22(p=0.01)$ in patients outside-cluster, $1.61 \pm$ $0.22(p=0.002)$ in patients in-cluster, $1.64 \pm 0.22(p=$ 0.008 ) in chronic $\mathrm{CH}$ (figure 2). Hypothalamic NAA/Cr did not show statistical differences among the subgroups of patients with $\mathrm{CH}$. No statistical difference was found between hypothalamic Cho/Cr values in healthy controls and the three subgroups of patients.

In patients with $\mathrm{CH}$, the mean $\mathrm{NAA} / \mathrm{Cr}$ in the parietaloccipital cortex $(1.37 \pm 0.14)$ and white matter $(1.67 \pm$

1264 Copyright (ㄷ) 2006 by AAN Enterprises, Inc 
Table Demographic and clinical data of patients with cluster headache

\begin{tabular}{|c|c|c|c|}
\hline $\begin{array}{l}\text { Episodic CH patients: } \\
\text { out of cluster/case no. }\end{array}$ & $\begin{array}{l}\text { Age, y/sex/age } \\
\text { at onset, y }\end{array}$ & $\begin{array}{l}\text { Interval from the end of } \\
\text { last cluster-MRS, mo }\end{array}$ & Therapy \\
\hline 1 & $45 / \mathrm{M} / 26$ & 1 & None \\
\hline 2 & $34 / \mathrm{M} / 27$ & 1 & None \\
\hline 3 & $55 / \mathrm{M} / 46$ & 9 & None \\
\hline 4 & $52 / \mathrm{M} / 33$ & 9 & None \\
\hline 5 & 49/M/17 & 14 & None \\
\hline 6 & $42 / \mathrm{M} / 24$ & 14 & None \\
\hline 7 & $39 / \mathrm{M} / 29$ & 12 & None \\
\hline 8 & $39 / \mathrm{M} / 29$ & 5 & None \\
\hline $\begin{array}{l}\text { Episodic CH patients: } \\
\text { in cluster/case no. }\end{array}$ & $\begin{array}{l}\text { Age, y/sex/age } \\
\text { at onset, y }\end{array}$ & $\begin{array}{l}\text { Cluster duration } \\
\text { at MRS, d }\end{array}$ & Therapy \\
\hline 9 & $63 / \mathrm{M} / 46$ & 12 & $\mathrm{~V}$ \\
\hline 10 & $54 / \mathrm{M} / 22$ & 21 & M \\
\hline 11 & $51 / \mathrm{M} / 20$ & 5 & $\mathrm{~V}, \mathrm{E}$ \\
\hline 12 & $36 / \mathrm{M} / 22$ & 31 & $\mathrm{~V}, \mathrm{E}$ \\
\hline 13 & $49 / \mathrm{F} / 28$ & 42 & $\mathrm{P}, \mathrm{D}$ \\
\hline 14 & $52 / \mathrm{M} / 38$ & 101 & $\mathrm{~V}$ \\
\hline 15 & $41 / \mathrm{M} / 35$ & 120 & $\mathrm{M}, \mathrm{L}$ \\
\hline 16 & $46 / \mathrm{F} / 39$ & 33 & $\mathrm{~V}, \mathrm{E}$ \\
\hline 17 & $31 / \mathrm{M} / 26$ & 27 & $\mathrm{~V}, \mathrm{E}$ \\
\hline 18 & $67 / \mathrm{M} / 58$ & 97 & $\mathrm{~V}, \mathrm{E}$ \\
\hline $\begin{array}{l}\text { Chronic } \mathrm{CH} \\
\text { patients/case no. }\end{array}$ & $\begin{array}{c}\text { Age, y/sex/age } \\
\text { at onset, y }\end{array}$ & $\begin{array}{c}\text { Chronic CH } \\
\text { since, mo }\end{array}$ & Therapy \\
\hline $19^{*}$ & $42 / \mathrm{M} / 40$ & 24 & $\mathrm{~V}$ \\
\hline $20^{*}$ & $59 / \mathrm{M} / 49$ & 120 & $\mathrm{~V}, \mathrm{~L}$ \\
\hline 21 & 49/M/32 & 18 & $\mathrm{P}, \mathrm{V}, \mathrm{C}$ \\
\hline $22^{*}$ & $47 / \mathrm{M} / 44$ & 36 & $\mathrm{~V}, \mathrm{M}$ \\
\hline 23 & $37 / \mathrm{M} / 18$ & 18 & $\mathrm{P}$ \\
\hline 24 & $48 / \mathrm{M} / 36$ & 104 & $\mathrm{E}$ \\
\hline 25 & $36 / \mathrm{M} / 34$ & 18 & $\mathrm{~L}$ \\
\hline 26 & $26 / \mathrm{M} / 15$ & 24 & $\mathrm{~V}, \mathrm{D}$ \\
\hline
\end{tabular}

* Cluster headache chronic at onset.

$\mathrm{CH}=$ cluster headache $\mathrm{MRS}=\mathrm{MR}$ spectroscopy; $\mathrm{V}=$ verapamil; $\mathrm{M}=$ methysergide; $\mathrm{E}=$ ergotamine; $\mathrm{P}=$ prednisone $; \mathrm{D}=$ dihydroergotamine; $\mathrm{L}=$ lithium $; \mathrm{C}=$ clonidine .

0.21) did not differ from that found in healthy volunteers (cortical $\mathrm{NAA} / \mathrm{Cr}=1.37 \pm 0.15, p=0.9$; white matter $\mathrm{NAA} / \mathrm{Cr}=1.64 \pm 0.22, p=0.7)$. Similarly, in patients with $\mathrm{CH}$, the mean $\mathrm{Cho} / \mathrm{Cr}$ in the cortex $(0.70 \pm 0.08)$ and white matter $(1.12 \pm 0.16)$ did not differ from that found in healthy volunteers (cortical Cho/Cr $=0.66 \pm 0.10, p=0.3$; white matter $\mathrm{Cho} / \mathrm{Cr}=1.09 \pm 0.11, p=0.6$ ).

No correlations were found between ${ }^{1} \mathrm{H}-\mathrm{MRS}$ variables and years from onset, cluster duration (for patients with episodic $\mathrm{CH}$ in-cluster), interval from the end of the last cluster (for patients with episodic $\mathrm{CH}$ out-cluster), and duration of the chronic $\mathrm{CH}$ condition (for patients with chronic $\mathrm{CH})$.

Discussion. We demonstrated that the neuronal marker NAA is reduced in the hypothalamus of patients with $\mathrm{CH}$ examined during an attack-free state.

NAA is found primarily in mature neurons and neuronal processes and is therefore considered a neuronal marker in mature human brains. Decreased NAA content is observed in pathologic processes in which neuronal loss occurs, such as degenerative disorders, stroke, and glial tumors, but also in the presence of neuronal dysfunction such as temporal lobe epilepsy and multiple sclerosis, in which therapeutic interventions may be associated with an increase in NAA content. ${ }^{5,6}$ VBM-MRI disclosed an increase in hypothalamic gray matter volume in patients with $\mathrm{CH}^{3}$ Abnormalities were bilateral and were similar in patients examined during active headache and in a headache-free state. ${ }^{3}$

VBM-MRI findings taken together with our ${ }^{1} \mathrm{H}$ MRS results show that the hypothalamus of patients with $\mathrm{CH}$ has an increased density of neurons associated with reduced $\mathrm{NAA} / \mathrm{Cr}$. A relative increase in hypothalamic gray matter in patients with $\mathrm{CH}$ can per se contribute to the observed reduced NAA/Cr as NAA content is lower in gray than white matter. ${ }^{7}$ Reduced NAA content in a brain area where the number of neurons is normal or, as possible in $\mathrm{CH}$, increased, could also suggest the presence of either immature or dysfunctional neurons expressing less NAA. This is the case, for example, in a brain area with heterotopic gray matter where an increased number of neurons that are normal-appearing and with active synapses may show reduced NAA content. ${ }^{8}$

In healthy subjects, a relationship has been found between the brain concentration of NAA and adenosine diphosphate,${ }^{9}$ the major regulator of mitochondrial oxidative phosphorylation. As ${ }^{31} \mathrm{P}-\mathrm{MRS}$ disclosed a bioenergetics deficit in the occipital cortex of patients with $\mathrm{CH},{ }^{10}$ we investigated, by as-
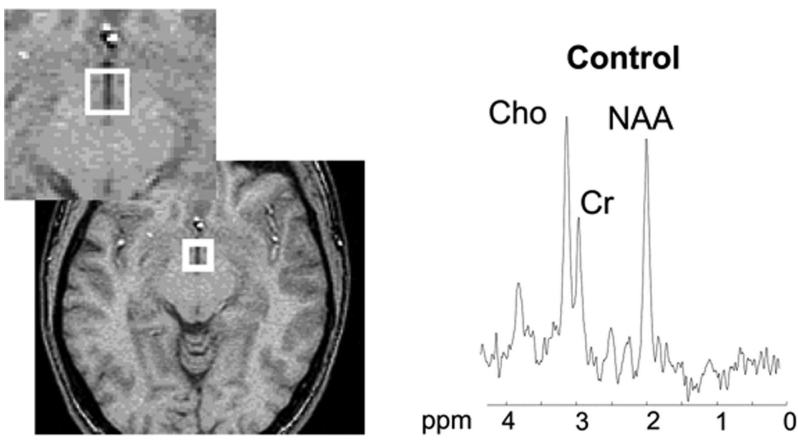

\section{$\mathrm{CH}$ patient}

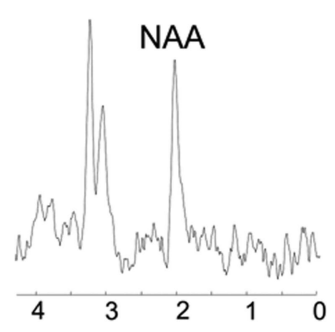

Figure 1. (Left) Axial fast gradient echo image showing hypothalamic voxel localization. Center and right: proton spectra $(T R=1500 \mathrm{msec} ; T E=144 \mathrm{msec})$ from a healthy volunteer and a patient with episodic cluster headache $(\mathrm{CH})$ outside the cluster period. In the patient, the $N$-acetylaspartate (NAA) peak is markedly reduced compared to that of the healthy volunteer. $\mathrm{Cr}=$ total creatine; Cho $=$ choline; ppm $=$ part per million . 


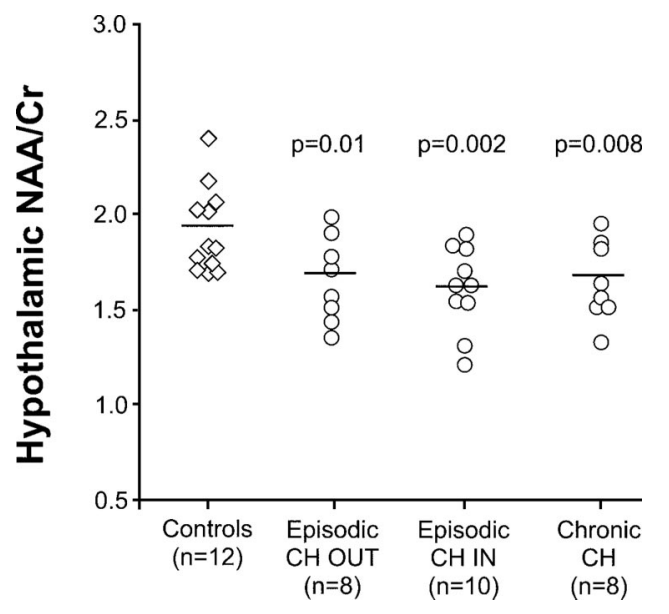

Figure 2. Hypothalamic $N$-acetylaspartate/creatine (NAA/ Cr) in healthy subjects, in patients with episodic cluster headache $(\mathrm{CH})$ out-and in-cluster periods, and in patients with chronic $\mathrm{CH}$. NAA/Cr was significantly reduced (Fisher's protected least significant difference test) in the hypothalamus of all subgroups of patients. Horizontal bars indicate groups' mean value.

sessing NAA levels in two extrahypothalamic hemispheric VOIs, whether the reduced hypothalamic $\mathrm{NAA} / \mathrm{Cr}$ in $\mathrm{CH}$ could be related to a nonspecific result of a diffuse brain bioenergetics deficit. The detection of normal levels of NAA/Cr in the cortex and white matter of our patients with $\mathrm{CH}$ tends to exclude that the reduction in hypothalamic NAA may be secondary to a diffuse brain bioenergetics deficit.

Our study detected a reduced NAA/Cr in the hypothalamus of patients with $\mathrm{CH}$, a neurochemical abnormality consistent with both relative increase in gray matter content and neuronal dysfunction. All examined patients were in a headache-free state during the ${ }^{1} \mathrm{H}-\mathrm{MRS}$ scan. This makes it unlikely that the reduction in $\mathrm{NAA} / \mathrm{Cr}$ is secondary to headache attacks and activation of central pain mechanisms per se. The finding that $\mathrm{NAA} / \mathrm{Cr}$ is also reduced in the group of patients with $\mathrm{CH}$ outside the cluster period and free from therapy indicates that such alteration is a permanent feature of patients with $\mathrm{CH}$. Although the mechanism leading to hypothalamic $\mathrm{NAA} / \mathrm{Cr}$ reduction in patients with $\mathrm{CH}$ is not known, low NAA/Cr may be an expression of neuronal hypothalamic malfunction that combined with other factors triggers headache attacks.

\section{References}

1. Headache Classification Committee of the International Headache Society. Classification and diagnostic criteria for headache disorders, cranial neuralgias and facial pain. Cephalalgia 2004;24(suppl 1):1-160.

2. May A, Bahra A, Buchel C, Frackowiak RS, Goadsby PJ. Hypothalamic activation in cluster headache attacks. Lancet 1998;352:275-278.

3. May A, Ashburner J, Buchel C, et al. Correlation between structural and functional changes in brain in an idiopathic headache syndrome. Nat Med 1999;5:836-838.

4. Lodi R, Tonon C, Vignatelli L, et al. In vivo evidence of neuronal loss in the hypothalamus of narcoleptic patients. Neurology 2004;63:15131515

5. Narayanan S, De Stefano N, Francis GS, et al. Axonal metabolic recovery in multiple sclerosis patients treated with interferon beta-1b. J Neurol 2001;248:979-986.

6. Cendes F, Andermann F, Dubeau F, Matthews PM, Arnold DL. Normalization of neuronal metabolic dysfunction after surgery for temporal lobe epilepsy. Evidence from proton MR spectroscopic imaging. Neurology 1997;49:1525-1533.

7. Schuff N, Ezekiel F, Gamst AC, et al. Region and tissue differences of metabolites in normally aged brain using multislice $1 \mathrm{H}$ magnetic resonance spectroscopic imaging. Magn Reson Med 2001;45:899-907.

8. Li LM, Cendes F, Bastos AC, Andermann F, Dubeau F, Arnold DL. Neuronal metabolic dysfunction in patients with cortical developmental malformations: a proton magnetic resonance spectroscopic imaging study. Neurology 1998;50:755-759.

9. Pan JW, Takahashi K. Interdependence of N-acetyl aspartate and highenergy phosphates in healthy human brain. Ann Neurol 2005;57:92-97.

10. Lodi R, Iotti S, Cortelli P, et al. Deficient energy metabolism is associated with low free magnesium in the brains of patients with migraine and cluster headache. Brain Res Bull 2001;54:437-441. 


\section{Neurology}

Study of hypothalamic metabolism in cluster headache by proton MR spectroscopy

R. Lodi, G. Pierangeli, C. Tonon, et al.

Neurology 2006;66;1264-1266

DOI 10.1212/01.wnl.0000208442.07548.71

\section{This information is current as of April 24, 2006}

\section{Updated Information \&} Services

References

Citations

Subspecialty Collections

Permissions \& Licensing

Reprints including high resolution figures, can be found at: http://www.neurology.org/content/66/8/1264.full.html

This article cites 10 articles, 4 of which you can access for free at: http://www.neurology.org/content/66/8/1264.full.html\#\#ref-list-1

This article has been cited by 5 HighWire-hosted articles: http://www.neurology.org/content/66/8/1264.full.html\#\#otherarticles

This article, along with others on similar topics, appears in the following collection(s):

\section{All Headache}

http://www.neurology.org//cgi/collection/all_headache

Cluster headache

http://www.neurology.org//cgi/collection/cluster_headache

\section{MRS}

http://www.neurology.org//cgi/collection/mrs

Information about reproducing this article in parts (figures,tables) or in its entirety can be found online at:

http://www.neurology.org/misc/about.xhtml\#permissions

Information about ordering reprints can be found online: http://www.neurology.org/misc/addir.xhtml\#reprintsus

Neurology ${ }^{\circledR}$ is the official journal of the American Academy of Neurology. Published continuously since 1951, it is now a weekly with 48 issues per year. Copyright . All rights reserved. Print ISSN: 0028-3878. Online ISSN: 1526-632X.

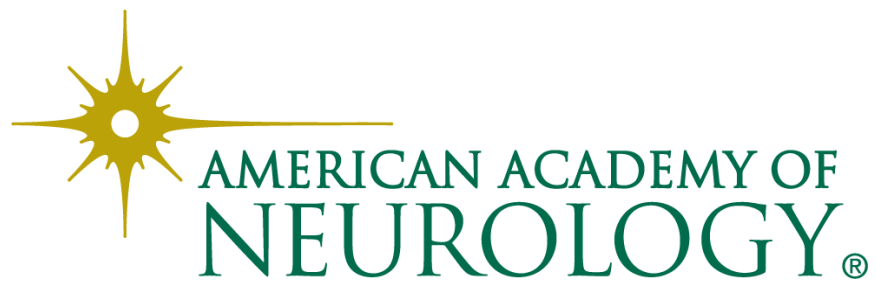

